\title{
Epidemiological situation of pertussis and strategies to control it. Argentina, 2002-2011
}

\author{
Viviana Romanin, M.D., ${ }^{a}$ Vanina Agustinho, B.S., ${ }^{a}$ Gloria Califano, M.D., ${ }^{a}$ \\ Sandra Sagradini, , M.D., Analía Aquino, B.S., ${ }^{a}$ María del Valle Juárez, M.D., ${ }^{a}$ \\ Julián Antman, B.S., ${ }^{b}$ Carlos Giovacchini, B.S., ${ }^{b}$ Marcelo Galas, M.D., Claudia Lara, \\ Biochemist, ${ }^{c}$ Daniela Hozbor, M.D., ${ }^{d}$ Ángela Gentile, M.D. ${ }^{e}$, and Carla Vizzotti, M.D. ${ }^{a}$
}

\section{ABSTRACT}

Introduction. Pertussis is a challenge for public health. Objectives: To describe pertussis-related morbidity and mortality and immunization coverage for the 2002-2011 period, profile of cases for 2011, and control strategies implemented by the Ministry of Health $(\mathrm{MoH})$ of Argentina. Methods. Descriptive, epidemiological surveillance study. Morbidity data were obtained from the National Health Surveillance System, while mortality data were obtained from the MoH's Health Statistics and Information Department and official jurisdictional reports. Administrative immunization coverage was used based on the data provided by the MoH's jurisdictions. The Epi Info software, version 7.1.2, was used for analysis.

a. National Program for the Control of Vaccine-Preventable Diseases (Programa Nacional de Control de Enfermedades Inmunoprevenibles, ProNaCEI), Ministry of Health of

Argentina.

b. Board of

Epidemiology, Ministry of Health of Argentina.

c. National Reference Laboratory for Pertussis, INEIANLIS "Dr. Carlos G. Malbrán."

d. National Reference Laboratory for Pertussis, VacSal, Institute of Biotechnology and Molecular Biology. School of Exact Sciences. Universidad Nacional de La Plata.

e. Sociedad Argentina de Pediatría.

E-mail Address:

Viviana Romanin, M.D. vivianaromanin@gmail. com

Conflict of Interest: None.

Received: 2-25-2014

Accepted: 6-5-2014

\section{INTRODUCTION}

Pertussis is a highly contagious acute respiratory disease caused by a bacterium called Bordetella pertussis. Universal immunization with the pertussis vaccine in children younger than 7 years old is critical for the control of this disease. ${ }^{1}$

Pertussis is, however, a challenge for public health, even in countries with high immunization coverage. Huge efforts have been made worldwide to achieve advances in reporting, diagnosing and preventing this condition. Most cases are described in infants younger than 6 months old, who have the highest rate of hospitalization, morbidity and mortality. ${ }^{1-4}$ This is an endemic/ epidemic disease, with outbreaks every 3-5 years. As per the World Health Organization's estimates, in 2008 there were 16 million cases of pertussis worldwide (95\% in developing countries) and 195000 deaths were recorded. ${ }^{5}$

The objectives of this study were to describe the evolution of pertussis morbidity and mortality and immunization coverage in the 2002-2011 period, to characterize the epidemiological profile of cases for 2011, and to describe control strategies implemented by the Ministry of Health $(\mathrm{MoH})$ of Argentina during this period.

\section{METHODS}

Descriptive, observational, and epidemiological surveillance study.

Data on morbidity: these were obtained from the National Health Surveillance System in Argentina (Sistema Nacional de Vigilancia de la Salud de Argentina, SNVS), agency 
that receives reports of notifiable diseases (Law 15465), including pertussis. The SNVS is a network that links the different providers located across the 24 jurisdictions of Argentina (23 provinces plus the Autonomous City of Buenos Aires) in a timely manner so that they can share and exchange information. Internet is the communication support system, and data are hosted in central servers. The SNVS software was developed in modules. For pertussis reporting, there are two modules: the clinical module (C2) and the laboratory module (SIVILA). Both modules collect information from different sources: $\mathrm{C} 2$ from the medical practice (outpatient visits, ER Department or hospitalization), while SIVILA collects data from laboratories where samples are obtained, referred to or analyzed. The study population consisted of cases reported to the SNVS from January $1^{\text {st }}, 2002$ to December $31^{\text {st }}, 2011$. Morbidity was analyzed for the 2002-2011 period using cases reported to the C2 module, whereas cases confirmed in 2011 were reviewed by combining $\mathrm{C} 2$ and SIVILA modules using the algorithm recommended by the $\mathrm{MoH} \cdot{ }^{6-8}$

Data on mortality: these data were obtained from the MoH's Health Statistics and Information Department (Dirección de Estadística e Información en Salud, DEIS); and in 2011, official reports from provinces were also used. ${ }^{9}$

Cases were defined and classified as per the MoH's recommendations (see Annex). ${ }^{6,10-12}$

Rate estimates were calculated based on population data from the 2001 and 2010 censuses, conducted by the National Statistics and Censuses Institute of Argentina, as applicable. Immunization coverage estimates were calculated based on the administrative coverage (ratio between the number of doses administered and the number of individuals to be vaccinated over 100), according to data provided by jurisdictions participating in the MoH's National Program for the Control of Vaccine-Preventable Diseases (Programa Nacional de Control de Enfermedades Inmunoprevenibles, ProNaCEI).

For laboratory detection of Bordetella pertussis infections, microbiological (culture) and molecular techniques were used based on the polymerase chain reaction (PCR) performed on nasopharyngeal aspirates (specimens of choice) or nasopharyngeal swabs at the laboratories located across the different jurisdictions of Argentina. The working algorithm was that recommended by the two national reference laboratories (NRLs): the VacSal, corresponding to the School of Exact
Sciences of Universidad Nacional de La Plata, and the National Infectious Disease Institute (Instituto Nacional de Enfermedades Infecciosas, INEI) - ANLIS “Dr. Carlos G. Malbrán," as per the recommendations made by the World Health Organization (WHO) and the US Centers for Disease Control and Prevention (CDC). Serological assays are performed at the INEI-ANLIS "Dr. Carlos G. Malbrán."

Regan Lowe and Bordet Gengou media supplemented with horse or sheep blood $(10 \%-15 \% \mathrm{v} / \mathrm{v})$ and plates with and without cephalexin at $40 \mathrm{ug} / \mathrm{mL}$ were used for cultures. Plates were seeded with patients' secretions and visually inspected up to 10 days following incubation before being considered negative. ${ }^{13}$ End-point PCR (conventional PCR) and/or realtime PCR were used for molecular diagnosis. Bordetella pertussis DNA by end-point PCR was detected using the IS481 insertion sequence and the pertussis toxin (ptx) promoter as target sequences. ${ }^{14,15}$ For real-time PCR, multiplex and singleplex assays were performed using the CDC's platform. ${ }^{16}$

For serological diagnosis, anti-Bordetella spp. antibody titers were assessed using ELISA (with serum samples collected at a 21-day interval), and a difference of two or more titers between both serum samples was considered positive.

Data were analyzed using the Epi Info 7.1.2 software.

\section{RESULTS \\ Epidemiological data for the 2002-2011 period}

The number of suspected cases reported showed an increasing trend, reaching the highest rate in 2011: 16 x 100000 inhabitants (Figure 1). The highest number of pertussis-related deaths was recorded in 2011, and all deaths occurred in the group of infants younger than 1 year old, except for five cases in the following age groups: 1-4 years old (3), 25-34 years old (1), and older than 75 years old (1) (Figure 2).

\section{National pertussis immunization coverage for the 2002-2011 period}

Coverage achieved with the third dose and with the dose administered at the time of starting primary education was over $90 \%$, while the 18-month booster dose achieved $80 \%-90 \%$ coverage (Figure 1). The booster dose at 11 years old, introduced in the immunization schedule since 2009 , achieved a $54.6 \%$ and a $72.8 \%$ coverage in 2010 and 2011, respectively. 
FIGURE 1. Reporting of pertussis cases and selected immunization coverage. Argentina, 2002-2011

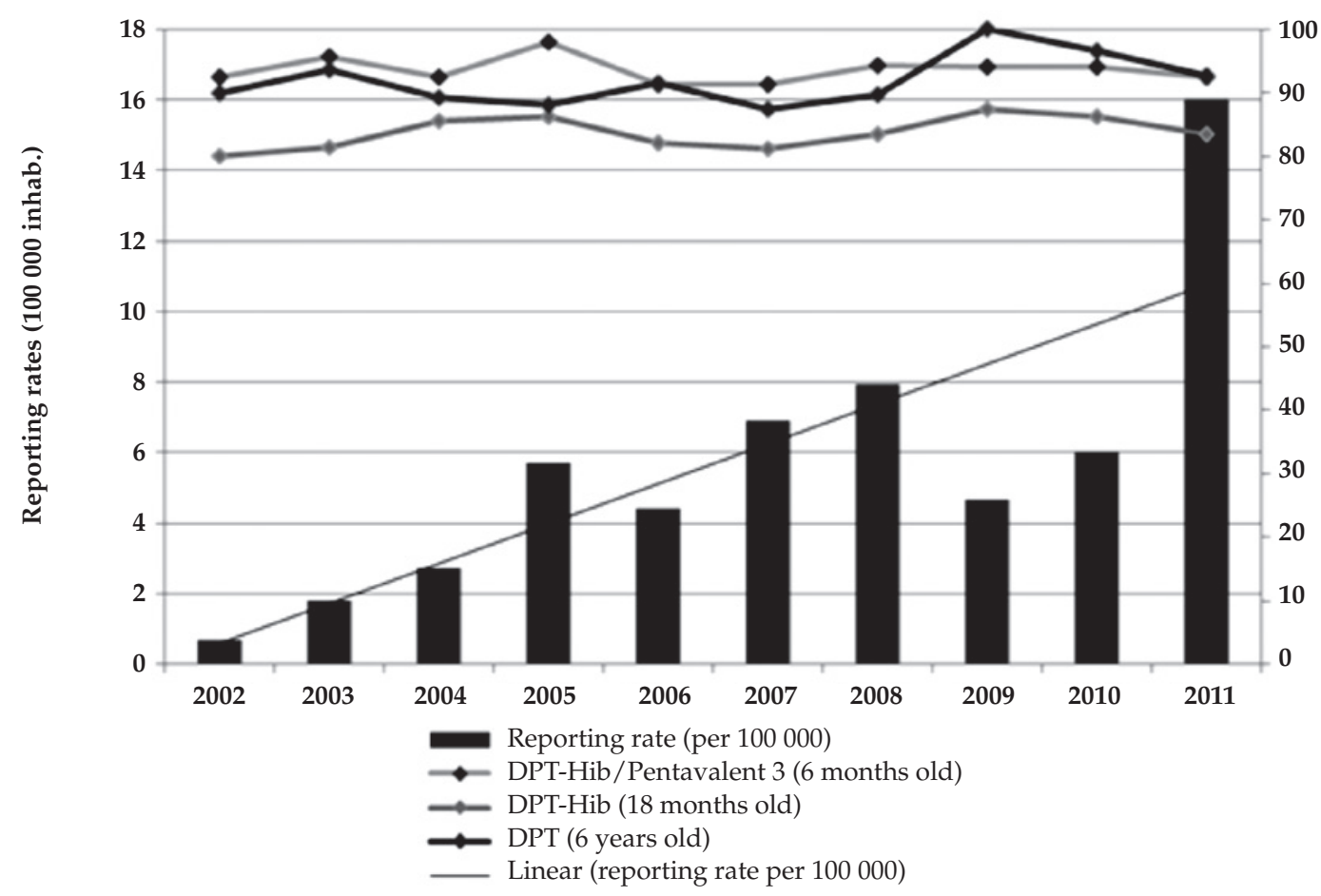

Source: C2-SNVS and National Program for the Control of Vaccine-Preventable Diseases. Ministry of Health of Argentina.

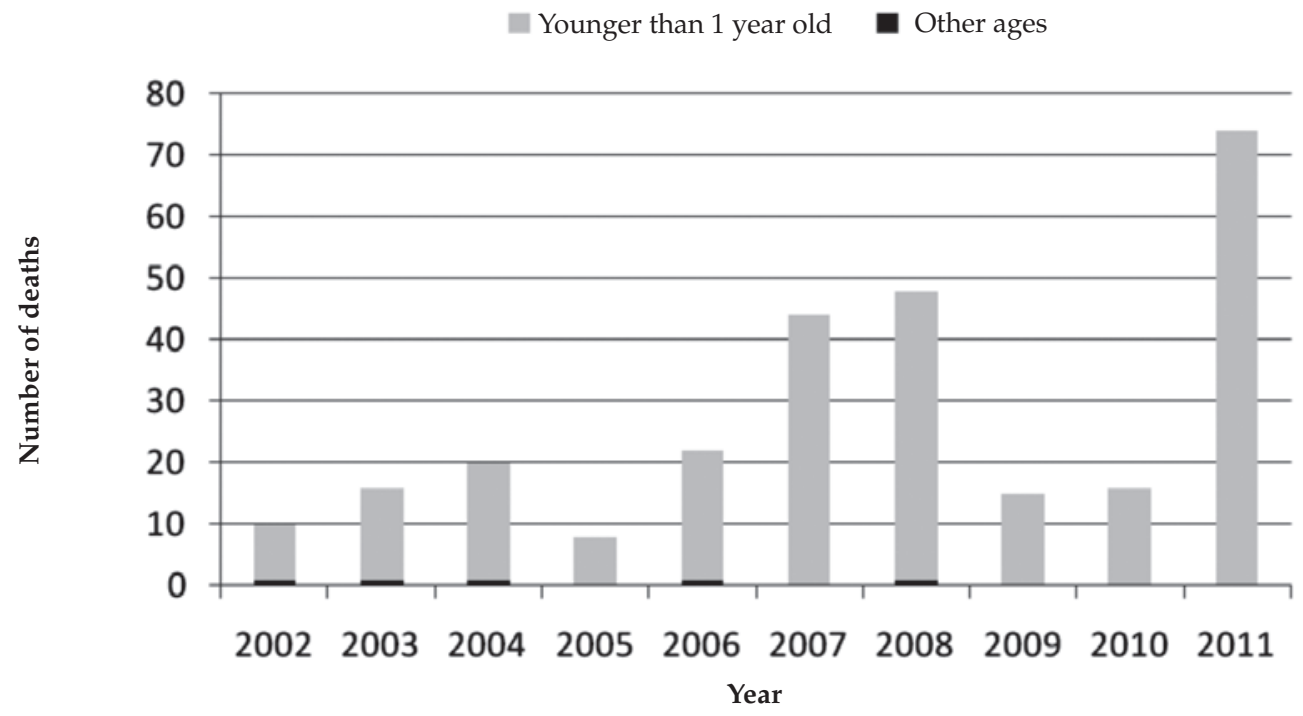

Source: Health Statistics and Information Department (Dirección de Estadística e Información en Salud, DEIS). Ministry of Health of Argentina. 


\section{Epidemiological data for cases confirmed in 2011}

A total of 10395 suspected cases were reported; of these, $2821(27 \%)$ were classified as confirmed; 1928 had positive lab tests, and 893 were confirmed with the clinical module. Confirmed cases were recorded in all weeks of the year, increasing as of epidemiological week (EW) 36. The minimum number of cases (17) was recorded in EW 19, while the maximum (107) was recorded in EW 44 and 45. The median number of cases reported by week was 46 . Ninety-nine percent (2784) of cases included data on age: $84 \%$ were infants younger than 1 year old, $54 \%$ were younger than 4 months old and $21 \%$ were younger than 2 months old (Figure 3). The incidence rate was $7 \times 100000$ inhabitants, while that corresponding to infants younger than 1 year old was $344 \times 100000$ inhabitants (Table 1). Sex distribution was similar: $51 \%$ were girls.

Confirmed cases were recorded in all provinces, except in La Rioja. Distribution by province was asymmetrical: the highest incidence rates were recorded in Neuquén, Chaco, Buenos Aires and Santa Fe; in the younger than 1 year old group, the highest incidence was recorded in Chaco, Santa Fe and Buenos Aires (Table 1).

Four provinces had incidence rates higher than the national rate; three of them (Chaco, Buenos Aires and Neuquén) issued outbreak alerts or reported them nationwide.
According to data collected by SIVILA, $1181 / 1928$ had immunization information: $426 / 1181$ were younger than 2 months old and had no indication for vaccination as per our national immunization schedule; 290/1181 had been fully vaccinated for their age; and 465/1181 had not completed their immunization schedule for their age.

According to the DEIS, 74 deaths occurred in 2011, all were infants younger than 1 year old. According to the jurisdictional data reported to the ProNaCEI, 76 deaths occurred in 2011: 74 in infants younger than 1 year old, and 2 in 1 year old infants. The case fatality rate was $2.69 \%$ of the total number of confirmed cases, and 3.14\% among infants younger than 1 year old. Of all deaths, $89.5 \%$ (68/76) occurred in infants younger than 4 months old, while $60.5 \%(46 / 76)$ in infants younger than 2 months old. No immunization data was recorded in $15.8 \%(12 / 76)$ of cases; $15.8 \%(12 / 76)$ had an incomplete immunization schedule, while $7.9 \%(6 / 76)$ had completed their immunization schedule (5 infants had received 1 dose, and 1 infant had received 3 doses).

\section{Strategies implemented by the $\mathrm{MoH}$}

- 2003: The SNVS was developed as a network that uses Internet as communication support to be able to establish a timely connection among the different providers working in the health sector. Following its creation, the

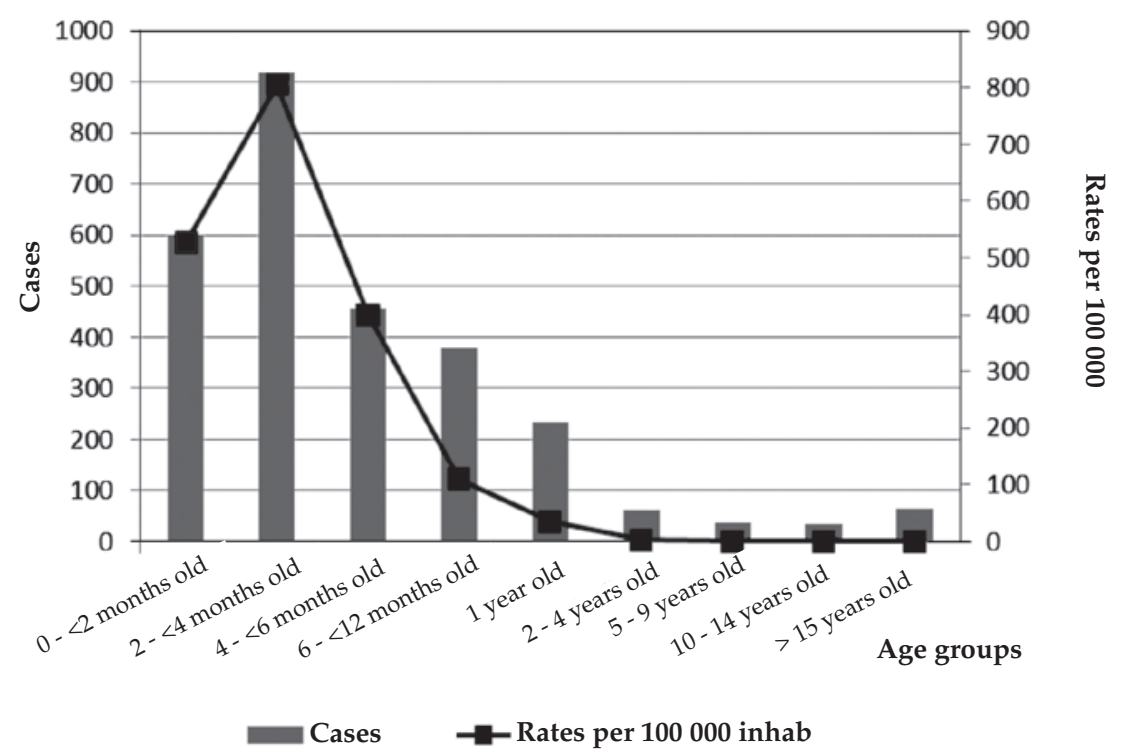

Source: SNVS; National Ministry of Health of Argentina. 
TABLE 1. Number of patients, pertussis incidence rates (overall and $<1$ year old) and immunization coverage by province. Argentina, 2011

\begin{tabular}{|c|c|c|c|c|c|c|}
\hline Province & $\begin{array}{c}\text { Total number } \\
\text { of patients* }\end{array}$ & $\begin{array}{c}\text { Incidence rate } \\
\text { x } 100000 \text { inhab.* }^{*}\end{array}$ & $\begin{array}{l}\text { Patients } \\
<1 \text { year old* }\end{array}$ & $\begin{array}{c}\text { Incidence rate } \\
<1 \text { year old } \times 100000^{*}\end{array}$ & $\begin{array}{l}\text { DPT-Hib-HB } \\
3^{\text {rd }} \text { dose } \%\end{array}$ & $\begin{array}{c}\text { DPT-Hib } \\
4^{\text {th }} \text { dose } \% * * \\
\end{array}$ \\
\hline Buenos Aires & 1583 & 10 & 1329 & 500 & 90.3 & 76.1 \\
\hline \multicolumn{2}{|c|}{ Aut. City of Buenos Aires 139} & 5 & 118 & 331 & 88.5 & 88.4 \\
\hline Catamarca & 23 & 6 & 22 & 340 & 99.6 & 81.5 \\
\hline Chaco & 114 & 11 & 101 & 514 & 105.7 & 86.5 \\
\hline Chubut & 16 & 3 & 15 & 161 & 93.3 & 82.7 \\
\hline Córdoba & 169 & 5 & 148 & 280 & 89.7 & 91.9 \\
\hline Corrientes & 38 & 4 & 37 & 202 & 93.7 & 92.3 \\
\hline Entre Ríos & 56 & 5 & 43 & 213 & 82.4 & 76.6 \\
\hline Formosa & 5 & 1 & 5 & 50 & 91.4 & 84.5 \\
\hline Jujuy & 11 & 2 & 9 & 73 & 106.7 & 105.0 \\
\hline La Pampa & 16 & 5 & 6 & 116 & 94.0 & 82.2 \\
\hline La Rioja & 0 & 0 & 0 & 0 & 84.5 & 77.9 \\
\hline Mendoza & 52 & 3 & 44 & 140 & 98.1 & 82.6 \\
\hline Misiones & 39 & 4 & 33 & 136 & 96.8 & 95.7 \\
\hline Neuquén & 65 & 12 & 30 & 290 & 102.2 & 94.8 \\
\hline Río Negro & 10 & 2 & 9 & 82 & 101.1 & 94.2 \\
\hline Salta & 60 & 5 & 50 & 194 & 96.8 & 90.1 \\
\hline San Juan & 28 & 4 & 25 & 341 & 95.2 & 71.3 \\
\hline San Luis & 1 & 0 & 1 & 18 & 99.2 & 94.1 \\
\hline Santa Cruz & 11 & 4 & 9 & 69 & 97.0 & 98.7 \\
\hline Santa Fe & 292 & 9 & 245 & 501 & 93.3 & 88.0 \\
\hline Sgo. del Estero & 2 & 0 & 2 & 11 & 87.0 & 98.4 \\
\hline Tierra del Fuego & 6 & 5 & 4 & 181 & 92.3 & 96.1 \\
\hline Tucumán & 45 & 3 & 37 & 139 & 93.1 & 85.8 \\
\hline Unknown & 40 & * & 33 & * & $*$ & $*$ \\
\hline Total & 2821 & 7 & 2355 & 344 & 92.5 & 83.6 \\
\hline
\end{tabular}

Source: * SNVS, Ministry of Health of Argentina. ${ }^{* *}$ National Program for the Control of Vaccine-Preventable Diseases.

distribution of participants progressively expanded to the 24 Argentine jurisdictions, reaching 906 clinical nodes and 405 laboratory nodes in 2011, all trained through workshops conducted in each province.

- 2005: PCR microbiological and molecular diagnostic methodologies were transferred from NRLs to the laboratories located in the different country jurisdictions.

- 2006: The C2 reporting mode and frequency were changed from a collective, weekly modality to an individual, immediate reporting.

- 2009: An adult triple bacterial acellular (dTpa) dose was introduced in the national immunization schedule at 11 years old and health workers who are in contact with infants younger than 1 year old.
- 2010: NRLs implemented the real-time PCR diagnostic methodologies transferred by the US Centers for Disease Control and Prevention (CDC), supported by the Latin American Pertussis Project.*

- 2011: The final epidemiological classification of cases was introduced in C2: suspected, probable, confirmed and ruled-out (such classification had not been previously used in the $\mathrm{C} 2$ module).

* The Latin American Pertussis Project is a collaborative project among the US Centers for Disease Control and Prevention (CDC), the Pan American Health Organization (PAHO), the Sabin Vaccine Institute, and the Latin American Ministries of Health selected to strengthen pertussis surveillance in Latin America. 
- 2011: Vaccination was recommended to household members if they lived with newborn infants with a birth weight of less than 1500 grams. At the end of 2011, the ProNaCEI summoned the National Advisory Committee on Immunization in order to agree on a proposal given the epidemiological situation of pertussis in Argentina and it was decided to administer a dTpa dose to pregnant women as of 20 weeks of gestation.

\section{DISCUSSION}

The increase observed in reporting as of 2002 is consistent with what has been reported in the past fifteen years in other countries with high levels of pertussis immunization (Australia, Canada, Italy, Japan, the Netherlands, Switzerland and the United States). ${ }^{4,17-21}$ In the United States, outbreaks have been reported in California $(2010)^{20}$ and Washington (2012) ${ }^{21}$; while in our region, in Chile $^{22}$ and Uruguay ${ }^{23}$ the number of reported cases of pertussis increased in 2011.

Most deaths in the 2002-2011 period occurred in infants younger than 1 year old, and this is the group with the highest rate of pertussis-related hospitalization, morbidity and mortality; the highest number of deaths was recorded in 2011.-6,24

Although in the 2002-2011 period, national immunization coverage reached over $80 \%$, it is worth noting that such coverage was administratively recorded which may pose certain errors: misrecording of administered doses (age, dose number, place of residence), estimation based on the doses shipped to the field instead of doses actually administered, or partial information regarding vaccines administered in the private sector.

In 2011, the recorded incidence rate was 7 per 100000 inhabitants, similar to that reported in the United States (6 per 100000 inhabitants). ${ }^{17}$ Infants younger than 1 year old were the predominant group among confirmed cases $(84 \%)$, with a specific incidence rate much higher than the overall rate, also consistent with the literature. ${ }^{1-5,17-23}$ The low rates recorded for infants and children older than 1 year old may reflect the underdiagnosis of pertussis in other age groups, situation that should be modified to detect potential sources of transmission to infants and changes in the epidemiology of this condition. The epidemics in California (2010 ${ }^{20}$ and Washington $(2012)^{21}$ resulted in high incidence rates in children aged 10 to 14 years old; as per 2011 United States reports, 38\% were children aged 5 to 14 years old, while $85 \%$ corresponded to infants and children older than 1 year old. ${ }^{17}$

In Argentina, pertussis surveillance has been strengthened: the data collection modality was changed from collective to individual data sheets, reporting increased and the system's sensitivity was improved through training workshops conducted in all provinces, new clinical and laboratory nodes were included in the providers' network, specificity on the access to B. pertussis diagnostic methods was optimized by NRLs where the implementation of molecular diagnosis in other Argentine laboratories was promoted. PCR was adopted as a confirmatory test given its swiftness and adequate specificity and sensitivity, as it happened in the United States (1996), France and Germany. ${ }^{4,25-27}$ Since 2011, based on the diagnostic improvement, SNVS introduced "epidemiological classification" as a variable, and defined pertussis cases as confirmed, probable and ruled-out; as a result, it was possible to estimate pertussis incidence more accurately, which is the main indicator of the immunization impact and is useful to monitor trends..$^{28}$ For this reason, there are no historical data of confirmed cases for the 2002-2010 period, since this final classification was not present in the $\mathrm{C} 2$ module.

In October 2011, the Advisory Committee on Immunization Practices (ACIP) published a recommendation to administer the dTpa vaccine to pregnant women in the United States, ${ }^{29}$ and several studies have demonstrated transplacental transfer of antibodies from mothers to babies. ${ }^{30}$ At the end of 2011, the ProNaCEI summoned the National Advisory Committee on Immunization and studied this strategy. Argentina was the first Latin American country where the dTpa vaccine was recommended for pregnant women aiming at reducing mortality in infants younger than 1 year old. ${ }^{31}$

The strengthening of epidemiological surveillance and the implemented immunization strategies $^{32,33}$ contrast the increased number of cases, especially considering that immunization coverage in infants and at the time of starting primary education remained stable in the studied period, reaching over $80 \%$. This situation may be the consequence of different factors:

1. The effectiveness of the vaccine to prevent the severe form of pertussis, following the third dose, is estimated to be $70 \%$ to $90 \%{ }^{3}$

2. Loss of immunity by the natural disease and induced by the vaccine; the latter may be significantly lost 5 to 8 years after the last 
booster dose.,4 The duration of protection may vary depending on whether vaccines used are whole-cell or acellular. ${ }^{34}$

3. Greater specificity and sensitivity of the surveillance system for detecting and confirming cases.

4. Suboptimal immunization rates, with differences that are not reflected in the overall rate of the country.

5. Underestimation of pertussis incidence in adolescents and young adults, who have milder clinical forms of pertussis that act as reservoirs and sources of infection.

6. There are B. pertussis strains circulating in the population which are antigenically distinct from those included in the vaccines being administered..$^{35}$

Weaknesses of our work include the lack of historical data regarding confirmed cases in the 2002-2010 period, and limitations in the information on immunization coverage collected through the administrative method; at present, a standardized national registry has been implemented to record administered doses.

Some of the strengths of this study are that it includes an analysis of a 10-year historical series of national data, an epidemiological profile of confirmed cases in 2011, and details on the advances made in pertussis surveillance.

The challenges presented by pertussis are closely related to the complexity of its control. A more effective vaccine conferring long-lasting immunity, should become available. Vaccination of pregnant women was implemented as a strategy to protect younger infants; its effectiveness and safety should be monitored. Meanwhile, existing control measures should not be neglected.

\section{CONCLUSIONS}

- In the 2002-2011period, reporting of cases of pertussis increased, most deaths occurred in infants younger than 1 year old, and the level of immunization coverage in infants and children at the time of starting primary education reached $80 \%$ and $90 \%$.

- In 2011, the distribution of cases in Argentina was heterogeneous, greater morbidity and mortality were observed in infants younger than 4 months old, and more than half of deceased infants were not old enough to have started their primary immunization schedule.

- In the studied period, the MoH strengthened the epidemiological surveillance of pertussis and introduced additional doses of pertussis vaccines.

\section{REFERENCES}

1. American Academy of Pediatrics. Pertussis (Whooping Cough). En: Pickering LK, ed. Red Book: 2012 Report of the Committee on Infectious Diseases. 29th ed. Elk Grove Village, IL: American Academy of Pediatrics; 2012. Págs.553-66.

2. Sociedad Argentina de Pediatría. Comité Nacional de Infectología. Bordetella Pertussis. En: Libro Azul de Infectología Pediátrica. 4ta ed. Buenos Aires: SAP; 2012.Págs.484-93.

3. Centers for Disease Control and Prevention. Epidemiology and Prevention of Vaccine-Preventable Diseases. 12th ed. Washington DC: Public Health Foundation, 2012. Chapter 15Pertussis. Available at: http: / / www.cdc.gov/vaccines / pubs/pinkbook/pert.html. [Accessed on: March 10,2013].

4. Tan T, Trindade E, Skowronski D. Epidemiology of pertussis. Pediatr Infect Dis J 2005;24(5 Suppl):S10-8.

5. World Health Organization. Immunization, Vaccines and Biologicals. Pertussis. Geneva: World Health Organization, 2012. Available at: http:/ / www.who.int/immunization/ topics/pertussis/en/index.html. [Accessed on: April 15, 2013].

6. Argentina. Ministerio de Salud de la Nación. Manual de normas y procedimientos de Vigilancia y Control de Enfermedades de Notificación Obligatoria. Revisión nacional 2007. Buenos Aires, 2007. Available at: http:// www. msal.gov.ar/images/stories/epidemiologia/pdf/ manual- normas-obligatorias.pdf. [Accessed on: April 20, 2013].

7. Argentina. Ministerio de Salud de la Nación. Vigilancia Clínica (C2). Buenos Aires, 2013. Available at: http:// www.msal.gov.ar/index.php/home/funciones/area-devigilancia/snvs-c2. [Accessed on: April 20, 2013].

8. Argentina. Ministerio de Salud de la Nación. SIVILA. Sistema Nacional de Vigilancia Epidemiológica por Laboratorios de Argentina. Buenos Aires, 2013. Available at: http:/ / www.msal.gov.ar/index.php/home/funciones/ area-de- vigilancia/sivila. [Accessed on: April 20, 2013].

9. Argentina. Ministerio de Salud de la Nación. Dirección de Estadística e Información en Salud. Defunciones de menores de 5 años. Indicadores seleccionados. Boletín número 139. BuenosAires:Dirección deEstadísticae InformaciónenSalud; 2013. Available at: http:/ / www.deis.gov.ar/ publicaciones / Archivos/Boletin139.pdf. [Accessed on: June 9, 2014].

10. Argentina. Ministerio de Salud. Manual de Normas y Procedimientos del Sistema Nacional de Vigilancia Epidemiológica. SI.NA.VE. - 1999. Revisión Internacional 2000. Buenos Aires, 2000.

11. Argentina. Ministerio de Salud de la Nación. Programa Nacional de Controlde Enfermedades Inmunoprevenibles. Actualización de la Situación de coqueluche. Alerta $\mathrm{N}^{\circ}$ Buenos Aires, 2001.[Accessed on: June 18, 2014]. Available at: http:/ /www.msal.gov.ar/images/stories / epidemiologia/inmunizaciones/alerta-sarampion/alertacoqueluche_agosto19-5B1-5D.pdf

12. Argentina. Ministerio de Salud de la Nación. Coqueluche sospechoso y coqueluche en estudios de contactos: normativa y tutorial para la vigilancia a través del sistema nacional de vigilancia laboratorial. SIVILA-SNVS. Actualización 2011. Buenos Aires, 2011. Available at: http:/ / www. msal.gov.ar/images/stories/epidemiologia/ vigilancia/ sivila/tutoriales/coqueluche-tutorialnormativa-para- notificacion-sivila-2011.pdf. [Accessed on: April 20, 2013].

13. World Health Organization. Immunization. Vaccines and Biologicals. Laboratory manual for the diagnosis of whooping cough caused by Bordetella pertussis/Bordetella parapertussis. Geneva: World Health Organization, 2007. Available at: http:/ / whqlibdoc.who.int/hq/2004/ WHO_ IVB_04.14_eng.pdf. [Accessed on: March 10, 2013]. 
14. GlareEM,Paton JC, Premier RR, LawrenceAJ, et al. Analysis of a repetitive DNA sequence from Bordetella pertussis and its application to the diagnosis of pertussis using the polymerase chain reaction. J Clin Microbiol 1990;28(9):1982-7.

15. Grimprel E, Bégué P, Anjak I, Betsou F, et al. Comparison of polymerase chain reaction, culture, and western immunoblot serology for diagnosis of Bordetella pertussis infection. J Clin Microbiol 1993;31(10):2745-50.

16. Tatti KM, Sparks KN, Boney KO, Tondella ML. Novel multitarget real-time PCR assay for rapid detection of Bordetella species in clinical specimens. J Clin Microbiol 2011;49(12):4059-66.

17. Adams DA, Gallagher KM, Jajosky RA, Kriseman J, et al. Summary of Notifiable Diseases - United States, 2011. MMWR Morb Mortal Wkly Rep 2013;60(53):1-117.

18. Plotkin S. Aims, scope and findings of the global pertussis initiative. Pediatr Infect Dis J 2005;24(5 Suppl):S5-6.

19. Halperin SA. The control of pertussis - 2007 and beyond. N Eng J Med 2007;356(2):110-3.

20. Winter K, Harriman K, Zipprich J, Schechter R, et al. California pertussis epidemic, 2010. J Pediatr 2012;161(6):1091-6.

21. Centers for Disease Control and Prevention (CDC). Pertussis epidemic-Washington, 2012. MMWR Morb Mortal Wkly Rep 2012;61(28):517-22.

22. Chile.MinisteriodeSalud.DepartamentodeEpidemiología. Informe de coqueluche año 2011. Santiago de Chile, 2011. Available at: http://epi.minsal.cl/epi/html/bolets / reportes/Coqueluche/Tos_Final_2011.pdf. [Accessed on: March 25, 2013].

23. Uruguay. Ministerio de Salud Pública. Dirección General de la Salud, División de Epidemiología. Informe de actualización. Situación tos convulsa (a la semana epidemiológica 37 de 2012). Montevideo: Ministerio de Salud Pública; 2012. Available at: http:/ /www.msp. gub. uy/sites/default/files/archivos_adjuntos/Informe_tos_ convulsa_SETIEMBRE_2012\%20(4).pdf. [Accessed on: June 9, 2014].

24. Tanaka M, Vitek CR, Pascual FB, Bisgard KM, et al. Trends in pertussis among infants in the United States, 1980-1999. JAMA 2003;290(22):2968-75.

25. Cherry JD, Grimpel E, Guiso N, Heininger U, et al. Defining pertussis epidemiology: clinical, microbiologic and serologic perspectives. Pediatr Infect Dis J 2005;24(5 Suppl):S25-34.

26. Heininger U, Schmidt-Schläpfer G, Cherry JD, Stehr K. Clinical validation of a polymerase chain reaction assay for the diagnosis of pertussis by comparison with serology, culture, and symptoms during a large pertussis vaccine efficacy trial. Pediatrics 2000;105(3):E31.

27. Giammanco A, Nardone A, Pebody R, Kafatos G, et al. European Sero-Epidemiology Network 2: standardisation of immunoassay results for pertussis requires homogeneity in the antigenic preparations. Vaccine 2008;26(35):4486-93.

28. World Health Organization. Estimates of disease burden and cost-effectiveness. Geneva:World Health Organization: 2014. Available at: http:/ /www.who.int/immunization/ monitoring_surveillance/burden/estimates/en/. [Accessed on: June 9, 2014].

29. Centers for Disease Control and Prevention (CDC). Updated recommendations for use of tetanus toxoid, reduced diphtheria toxoid and acellular pertussis vaccine (Tdap) in pregnant women and persons who have or anticipate having close contact with an infant aged $<12$ monthsAdvisory Committee on Immunization Practices (ACIP), 2011. MMWR Morb Mortal Wkly Rep 2011;60(41):1424-6.

30. Leuridan E, Hens N, Peeters N, de Witte L, et al. Effect of a pregnancy pertussis booster dose on maternal antibody titers in young infants. Pediatr Infect Dis J 2011;30(7):60810.

31. Argentina. Ministerio de Salud de la Nación, Programa Nacional de Control de Enfermedades Inmunoprevenibles. Alerta epidemiológico 25/1/2012. Tos convulsa: aumento de casos y muertes. Buenos Aires; 2012. Available at: http://www.msal.gov.ar/images/stories/ bes / graficos / 0000000454cnt-2013-10_alerta-n01-tosconvulsa-2012.pdf. [Accessed on: June 9, 2014].

32. Argentina. Ministerio de Salud de la Nación. Calendario Nacional de Vacunación de la República Argentina 2012. Buenos Aires; 2012. Available at: http:/ /www.msal.gov. ar/images/stories/calendario-vacunacion/calendariovacunacion-2012.pdf. [Accessed on: June 9, 2014].

33. Argentina. Ministerio de Salud de la Nación, Secretaría de Promoción y Programas Sanitarios. Normas nacionales de vacunación. Edición 2008. Buenos Aires: OPS/OMS Argentina; 2008. Available at: http://publicaciones.ops. org.ar/publicaciones/otras\%20pub/Normas-Nacionalesde-Vacunacion-2008.pdf. [Accessed on: June 9, 2014].

34. Tartof SY, Lewis M, Kenyon C, White K, et al. Waning immunity to pertussis following 5 doses of DTaP. Pediatrics 2013;131(4):e1047-52.

35. Fingermann M, Fernández J, Sisti F, Rodríguez ME, et al. Differences of circulating Bordetella pertussis population in Argentina from the strain used in vaccine production. Vaccine 2006;24(17):3513-21. 


\section{ANNEX}

Definitions of pertussis cases used in the 2002-2011 period:

2002-2007 period ${ }^{10}$ (weekly numerical reporting modality):

Suspected case: Individual with paroxysmal cough for, at least, 2 weeks, no fever, and one of the following symptoms: paroxysmal cough, inspiratory stridor, coughs with vomiting and coughing up spinnable mucus, with no other apparent cause.

Confirmed case: Suspected case with isolation of Bordetella pertussis on respiratory secretion (specimen) or an epidemiological link with a laboratory confirmed case.

\section{7-2011 period ${ }^{6}$ (individual-immediate reporting modality):}

Suspected case: Patient with cough for, at least, 14 days, no fever and one of the following symptoms: paroxysmal cough, inspiratory stridor, coughs with vomiting and coughing up spinnable mucus, with no other apparent cause.

In infants younger than 6 months old, paroxysms may not be present, but they may present with apnea and cyanosis. When there is an outbreak, the definition of case should be adjusted.

Confirmed case: Suspected case with isolation of Bordetella pertussis on respiratory secretion (specimen) or positive PCR or seroconversion between two serum samples collected during the acute phase and during the recovery period, or an epidemiological link with a laboratory confirmed case.

\section{$2011^{11}$ (individual-immediate reporting modality):}

Suspected case: Infants younger than 6 months old. Any acute respiratory tract infection with at least one of the following symptoms: apnea, cyanosis, inspiratory stridor, coughs with vomiting, or paroxysmal cough.

Children older than 6 months old and younger than 11 years old. Cough for 14 or more days accompanied with one or more of the following symptoms: paroxysmal cough, inspiratory stridor, or coughs with vomiting, with no other apparent cause.

Children older than 11 years old. Persistent cough for 14 or more days with no other symptoms.

Confirmed case: Patient with respiratory infection and cough of any duration, and positive culture for the causative agent.

Patient with clinical symptoms compatible with pertussis and positive lab results using specific PCR assays.

Patient with clinical symptoms compatible with pertussis and positive lab results (seroconversion) using a specific serological assay.

Patient with clinical symptoms compatible with pertussis and an epidemiological link with a laboratory confirmed case.

Probable case: Patient with clinical symptoms compatible with pertussis and no laboratory confirmation (not studied or inconclusive lab results), and no epidemiological link with a laboratory confirmed case.

Patient with incomplete clinical symptoms or insufficient data and a positive PCR or seroconversion result.

Ruled-out case: Incomplete clinical symptoms or insufficient data, negative lab result and no epidemiological link with a laboratory confirmed case. 